\title{
El ecosistema ruminal en bovinos y sus posibilidades de mejora
}

\section{J. Selva Andina Anim. Sci. 2019; 6(1):1-2.}

En el rumen del ganado bovino la población microbiana (ecosistema ruminal) está constituida por bacterias anaerobias estrictas, protozoos y hongos que pueden sobrevivir en condiciones anaeróbicas no estrictas, altos ritmos de dilución, densidades de células y depredación protozoaria, desarrollo de habilidades para el manejo efectivo de complejos polímeros vegetales. Los alimentos que llegan al rumen son fermentados hasta generar ácidos grasos volátiles (AGV), ingeridos y utilizados en procesos catabólicos y anabólicos. Por lo tanto, la fermentación presenta ventajas, además resultado de perdidas energéticas en forma de gas metano, hidrogeno y calor. Un ejemplo claro es cuando la glucosa sobrepasa el rumen (bypass) y por tanto se absorberá en el intestino delgado y su energía aumentaría en un $30 \%$.

El rumen es el encargado de fermentar y degradar polisacáridos estructurales por el elevado número de enzimas producidas por su microbiota (polisacaridasas), un ejemplo es la degradación de los arabinoxylanos, polisacáridos estructurales se encuentran normalmente en paredes celulares de forrajes y en parte, los cereales como el endospermo, ya que requieren una cantidad de enzimas que trabajen secuencialmente para el desdoblamiento de estos polisacáridos esencialmente el trabajo de enzimas que hidrolizan las cadenas de arabinosa como el grupo acetil, ácido glucurónico y ácido ferúlico ya que actuarán primero luego seguirán las xilanasas ya que fraccionan las principales cadenas de xilano.

Hoy en día se considera la especie rumiante, como uno de los mayores participantes que provocan el deterioro de la capa de ozono y como consecuencia estimulan al calentamiento global, debido a la libertad existente de gases en la atmósfera, entre ellos se menciona al metano y carbono. El gas metano es inducido por la fermentación del alimento que llega al rumen. La separación de estos gases, principalmente del $\mathrm{H}_{2}$ implica la remoción de un factor para la permanencia del $\mathrm{pH}$ ruminal que ayuda a la fermentación. Sin embargo, la producción de metano es considerada como una pérdida energética potencial aprovechable. Los efectos de las bacterias metanógenas son dependientes principalmente de sustratos presentes en la dieta y de las interacciones con otras poblaciones. La alimentación de los animales con alimentos como son los subproductos agrícolas están encaminadas a mejorar el proceso de fermentación en el rumen, que generalmente conducen a mejorar los parámetros productivos y reproductivos, por una mejor utilización de la energía. Asimismo, la disminución de los gases en la atmósfera contribuyendo al cuidado del ambiente.

Algunas manifestaciones han señalado que el índice de transferencia de metano producido por descomposición ruminal se encuentra vinculada tanto con características físicas como químicas de dicha dieta, por lo que éstas a su vez damnifican la nivelación tanto del consumo como de la frecuencia de la 


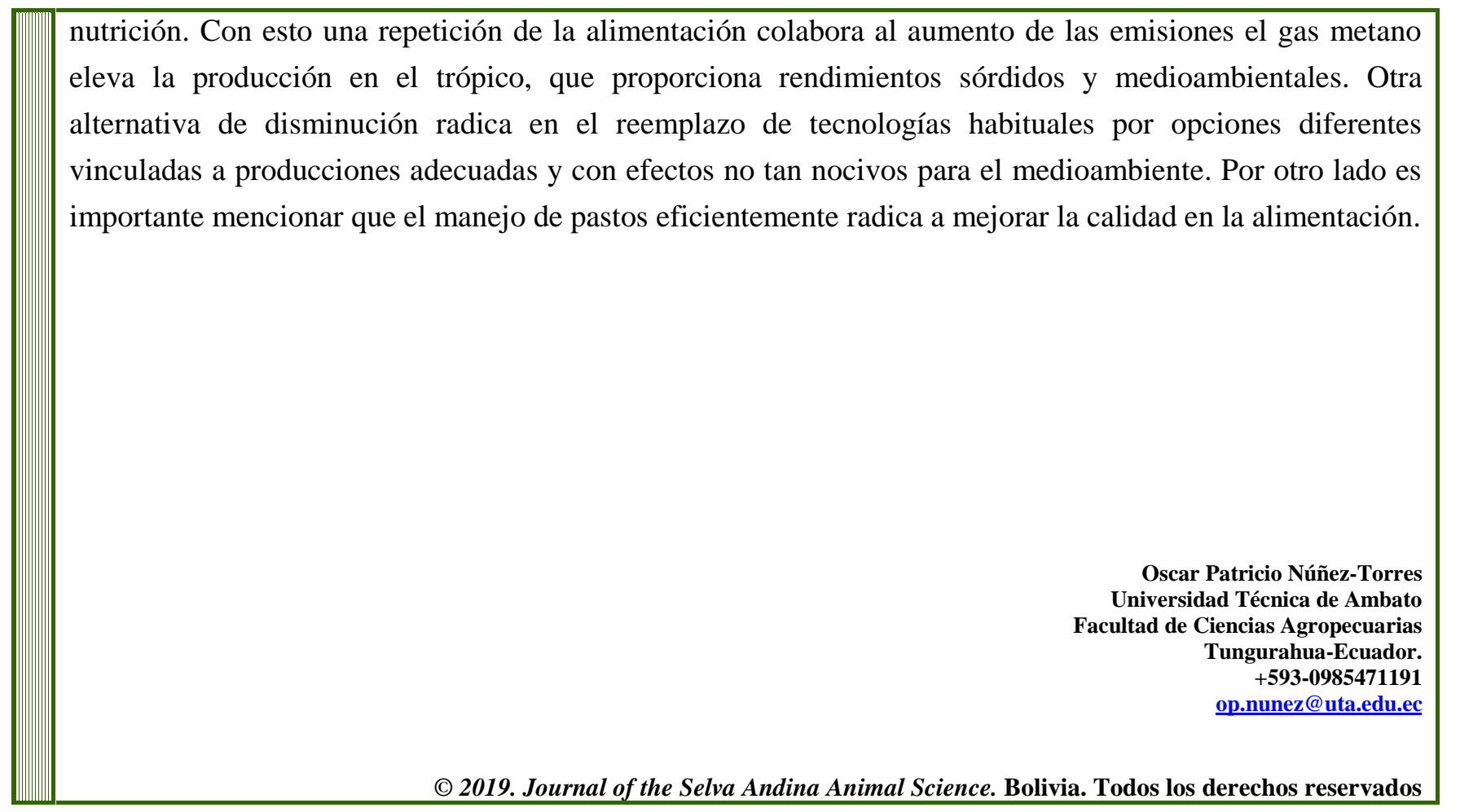

